J. Clin. Chem. Clin. Biochem.

Vol. 19, 1981, pp. $971-976$

\title{
Determination of Free Haemoglobin in Serum by an Automated Assay Using 4-Aminophenazone and the Cobas Bio System
}

\author{
By $K$. Bauer \\ Institute for Clinical Chemistry and Laboratory Medicine (Head Prof. Dr. F. Gabl) University of Vienna
}

(Received November 11, 1980/February 26, 1981)

Dedicated to Prof. Dr. Franz Gabl on the occasion of his 60 th birthday

Summary: A colorimetric method for the determination of free haemoglobin in human serum is described, using 4-aminophenazone as chromogen, and commercially available haemiglobin cyanide solutions as standards. The reaction system is suitable for manual measurements as well as determinations with a centrifugal analyser (Cobas Bio System). Accuracy, linearity and stability of the procedure is shown. A reference interval in sera of normal adults was established, with an upper limit of $5 \mathrm{mg} / \mathrm{dl}$. The alternative use of heparin plasma instead of serum is discussed.

\section{Bestimmung von freiem Hämoglobin in Serum durch eine automatisierte Methode mittels 4-Aminophenazon und dem Cobas Bio System}

Zusammenfassung: Eine kolorimetrische Methode zur Bestimmung von freiem Hämoglobin in menschlichem Serum wird beschrieben, die 4-Aminophenażon als Chromogen, und kommerziell verfügbare Hämiglobincyanid-Lösungen als Standards benutzt. Das Reaktionssystem ist sowohl für manuelle Messungen, als auch für Bestimmungen mit einem Zentrifugalanalysator (Cobas Bio System) geeignet. Genauigkeit, Linearität und Stabilität der Methode werden gezeigt. Ein Referenzintervall in Sera gesunder Erwachsener wurde ermittelt, sein oberer Grenzwert liegt bei $5 \mathrm{mg} / \mathrm{dl}$. Die alternative Verwendung von Heparinplasma an Stelle von Serum wird diskutiert.

\section{Introduction}

Elevated levels of free haemoglobin $(\mathrm{Hb})$ in serum or plasma are found in increased intravascular haemolysis caused by various disorders, action of toxic substances or mechanical stress on erythrocytes. Their rapid detection and reliable monitoring are necessary especially in cases of emergency.

The methods for measurement of free $\mathrm{Hb}$ in serum or . plasma are either spectrophotometric $(1,2,3)$ or colorimetric assays $(4,5)$. Since the standard methods using the carcinogenic compounds benzidine or 0 -toluidine are potentially häzardous (6), alternative methods have been proposed $(7,8)$.

All colorimetric assays use the pseudoperoxidase properties (8) of haemoglobin, which catalyses the reduction of hydrogen peroxide. Trinder (9) proposed a peroxidase reaction for the determination of blood glucose, and a similar indicator reaction is used in an enzymatic cholesterol assay (10). The chemical formulae of the indicator reactants are given in figure 1.
By omission of xenogenic peroxidase and addition of hydrogen peroxide in excess, this assay is a sensitive tool for the determination of peroxidase or pseudoperoxidase (e.g. free $\mathrm{Hb}$ ) activity. In meeting the requirements of routine clinical chemistry, the method was adapted for a manual procedure as well as for a centrifugal analyser of the latest generation.

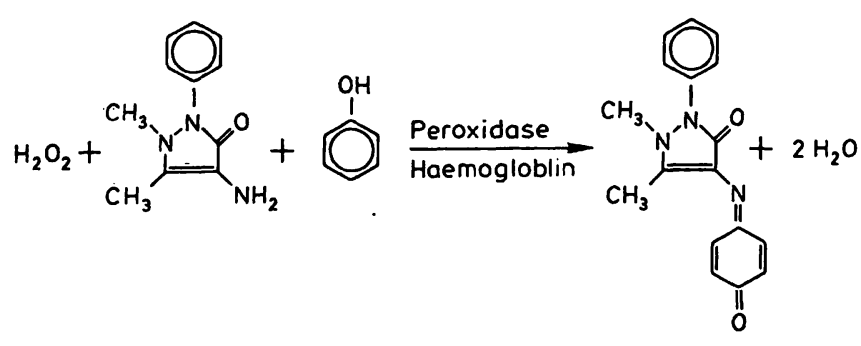

Fig. 1. Chemical formulac for the indicator reaction. Hydrogen peroxide reacts with 4-aminophenazone and phenol by catalysis by peroxidase or pseudoperoxidasc (c.g. hacmoglobin). 4-(p-benzoquinonc-monoimino)-phenazone is formed, with an absorption maximum at $500 \mathrm{~nm}$. 


\section{Materials and Methods}

$30 \mathrm{~g} / \mathrm{l}$ hydrogen peroxide was prepared from a $300 \mathrm{~g} / \mathrm{kg}$ stock solution (Chemosan $\mathrm{Ag}$, Vienna, Austria). Phenol ( $0.64 \mathrm{~mol} / \mathrm{l}$ ) and reagent $(0.8 \mathrm{~mol} / \mathrm{l}$ potassium phosphate buffer $\mathrm{pH} 7.2$; $2 \mathrm{~mol} / 1 \mathrm{methanol}, 1.9 \mathrm{mmol} / \mathrm{l}$ 4-aminophenazone and $80 \mathrm{~g} / \mathrm{l}$ hydroxypolyethoxydodecane) were taken from a cholesterol test kit (No 148393, Boehringer Mannheim, FRG). The working reagent solution was obtained by mixing $96.7 \mathrm{ml}$ of reagent with $1.0 \mathrm{ml}$ of phenol, and $3.3 \mathrm{ml}$ of glacial acetic acid (p.A. Merck, FRG) to adjust the $\mathrm{pH}$ of the final solution to 5.75. It was prepared daily and stored at room temperature in the dark. Alternatively the reagent solution was prepared with identical composition and $\mathrm{pH}$ from commercially available chemicals. They all were of analy tical grade and mostly purchased from Merck, FRG, except 4-aminophenazone (4-aminoantipyrine, 1-phenyl-2,3-dimethyl-4-aminopy razolone), which was from Serva, FRG. Hydroxy polyethoxydodecane was replaced by an equal concentration of $\mathrm{Brij}^{\circledR} 35$.

Haemiglobin cyanide was prepared with the reagent from a haemoglobin test kit (No 124729, Boehringer Mannheim, FRG). This contained $1 \mathrm{mmol} / 1$ potassium hydrogenphosphate, $0.75 \mathrm{mmol} / 1$ potassium cyanide and $0.6 \mathrm{mmol} / \mathrm{l}$ hexacyanoferrate(III). Detergent, as supplied with this kit, was added to a final concentration of $0.1 \mathrm{ml} / 1$ when indicated.

Haemiglobin cyanide standards were purchased from Merck, FRG. From the Lot 28263 we used the solutions containing $23.3,54.3$, and $80.2 \mathrm{mg} / \mathrm{dl}$. Human haemoglobin was prepared according to Bauer et al. (5). The manual assays were measured with a digital photometer (S 100, Labtronic AG, Zurich, Switzerland) at room temperature with $1 \mathrm{~cm}$ cuvettes, and the automated procedure was performed with a microprocessor-equipped centrifugal analyser (Cobas Bio System, Roche-Basel, Switzerland). Protein concentrations were determined with the Protein Assay (Biorad) according to Bradford (11).

\section{Specimen collection for the reference range}

After venipuncture with a $1.2 \mathrm{~mm}$ gauge needle, $10 \mathrm{ml}$ of the freely flowing blood were discarded (in fact used for other determinations) and subsequently about $5 \mathrm{ml}$ of blood collected in a glass tube. After coagulation at room temperature for $30 \mathrm{~min}$ the samples were centrifuged at $3000 \mathrm{~min}^{-1}$ for $10 \mathrm{~min}$. Supernates were removed carefully and centrifuged a second time to eliminate any ery throcy tes that may have been present.

\section{$o$-Toluidine method}

The o-toluidine method was performed according to Bauer ct al. (5), method " $A$ ", using $O$-toluidine instead of benzidine.

\section{Manual kinetic assay}

Mix $1.5 \mathrm{ml}$ of reagent working solution and $150 \mu \mathrm{l}$ of $30 \mathrm{~g} / \mathrm{l}$ hydrogen peroxide with $300 \mu \mathrm{l}$ of standard or serum in the cuvette. Read absorbance at $546 \mathrm{~nm}$, first point $1 \mathrm{~min}$ after mixing, second point 6 min after mixing. Calculate $\Delta A=A_{2}-$ $A_{1}$, establish a standard curve with the three haemiglobin cyanide standards and interpolate unknown values. Incubation and measurement at room temperature.

\section{Automated kinetic assay}

A summary of the data used is given in tab. 1. The Cobas Bio System is a centrifugal analyser capable of various types of analyses and calculations (12). At "Type of Analysis 3" the system works in enzyme start mode. Reagent and sample are pipetted together with diluent (water), mixed in the disposable plastic cuvette rotor and incubated during a spin of $20 \mathrm{~s}$. In a second step $30 \mu \mathrm{l}$ of $30 \mathrm{~g} / \mathrm{l}$ hydrogen peroxide is pipetted into the start reagent compartement of the cuvette. The components are mixed and incubated at $25^{\circ} \mathrm{C}$ during centrifugation for $100 \mathrm{~s}$. With the rotor still running 5 consecutive measurements of absorbance are then performed at intervals of 10 seconds against a reagent blank (= "blanking mode 1"). In ,printout mode 2 " the $\Delta \mathrm{A} / \mathrm{min}$ is calculated by linear regression using all points of measurement. For every run a separate standard curve is calculated from 3 haemiglobin cyanide standards. Working temperature is $25^{\circ} \mathrm{C}$. Statistics were done with a HewlettPackard 97 programmable calculator, using the manufacturer's programs.

Tab. 1. Parameter listing of the automated procedure. Items are explained in the text in detail.

TEST HF $1 \mathrm{E} F$ HE

DIEAE BID

\section{FAFAHETEF: LISTIHIS}

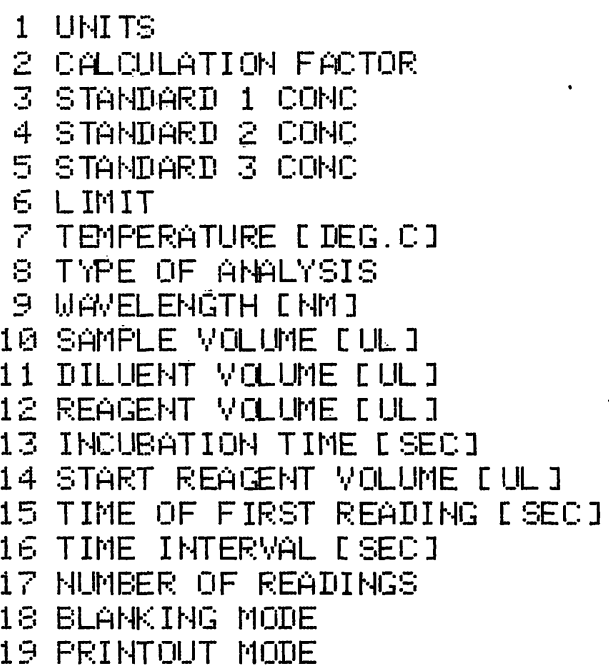

MITL

$$
\begin{aligned}
& \text { B日. } \\
& 54.3 \\
& 23.3 \\
& 150 \\
& 25.6 \\
& 5 \\
& 50 \\
& 10 \\
& 200 \\
& 20 \\
& 30 \\
& 100 \\
& 10 \\
& 95 \\
& 1
\end{aligned}
$$

\section{Results}

Due to greater speed, accuracy and convenience - compared to the manual method - all determinations were made with the automated method, except those which were needed for the comparisons of the automated $v s$. manual method. Routinely the premixed reagents from Boehringer Mannheim were used.

In order to show the linearity of the reaction, the standard program for the automated kinetic assay was changed, so that absorbances were measured every $10 \mathrm{~s}$ over a period of $280 \mathrm{~s}$, starting at zero reaction time. Absorbance as a function of time for 2 standards and two patient's sera is shown in figure 2. Time interval A corresponds with the incubation time of the standard program, time interval B with the measurement period. Samples with high concentrations of free $\mathrm{Hb}$ (above $50 \mathrm{mg} / \mathrm{dl}$ ) show a decrease of $\Delta \mathrm{A}$, especially at the beginning of the reaction. After $100 \mathrm{~s}$ incubation, stability of the kinetic reaction is acceptable for the automated calculation of the $\mathrm{Hb}$ concentration.

Accuracy was tested by measurement of haemoglobin concentrations in two different ways. Protein concentrations of 6 different dilutions of.a freshly prepared $\mathrm{Hb}$ solution in Tris buffered saline were determined with the Protein-Assay method. Corresponding amounts of this $\mathrm{Hb}$ preparation were diluted in: 


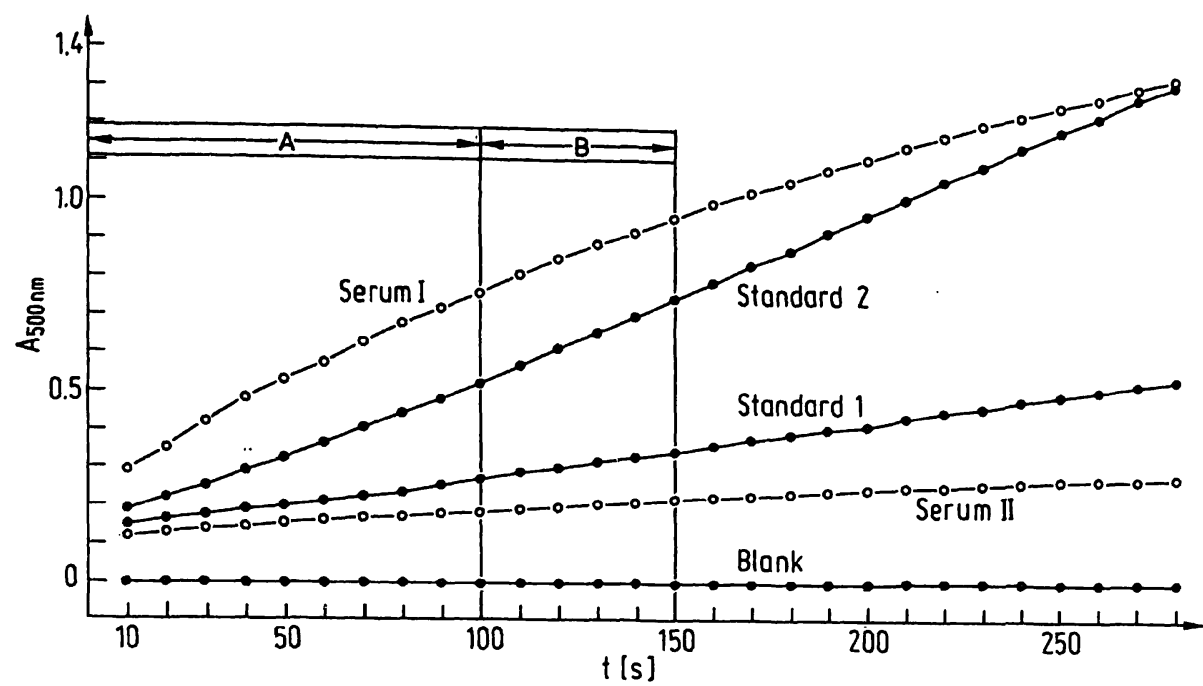

Fig. 2. Absorption at $500 \mathrm{~nm}$ as a function of time during the pseudoperoxidase reaction. Values of two haemiglobin cyanide standards: two sera and the reagent blank are shown. Time interval " $A$ " corresponds to the incubation period of the standard measuring program; time interval " $B$ " corresponds to its measurement period.

1. Normal human pool serum

2. Tris buffered saline $\mathrm{pH} 7.0$

3. Cyanide reagent without detergent

4. Cyanide reagent with detergent.

Determination of pseudoperoxidase activity was performed with the automated method; recovery compared to protein content (taken as 1.0) is shown in table 2. Haemiglobin cyanide standards (Merck) were used in both assays; their pseudo-peroxidase activity equals that of natural haemoglobin in serum, despite the chemical modification.

Tab. 2. Comparison of protein content $v s$. haemoglobin pseudoperoxidase activity in different media. Haemiglobin cyanide standard solutions (Merck) were used in both assays.

\begin{tabular}{ll}
\hline & $\begin{array}{l}\text { Relative } \\
\text { concentration } \\
\text { measured }\end{array}$ \\
\hline $\begin{array}{l}\text { Protein assay } \\
\text { Peroxidase activity }\end{array}$ & 1.000 \\
$\begin{array}{l}\text { Haemoglobin in serum } \\
\text { Haemoglobin in saline } \\
\text { Haemiglobincyanide without detergent }\end{array}$ & 0.992 \\
Haemiglobincyanide with detergent & 0.846 \\
\hline
\end{tabular}

Linearity of the method was checked by mixing two sera of different free $\mathrm{Hb}$ content in various proportions. Nominal $v$ s. found values are plotted in figure 3.

Correlation of the automated $v s$. manual kinetic procedure is given in figure 4, that of the automated assay $\nu s$. manual $o$-toluidine method in figure 5 .

Statistics on the variance of the automated method in serial determinations as well as day-to-day precision are shown in figure 6. For the latter, aliquots of 22 different sera were kept frozen at $-20^{\circ} \mathrm{C}$ until use. Note that the standards fit well to the curve.

A reference interval for this method was established by determination of free $\mathrm{Hb}$ in 104 carefully prepared sera from normal adult persons. The histogram (fig. 7a) shows a log-normal distribution. Using the probability net according to Barnett (13) we found a mean value of $1.46 \mathrm{mg} / \mathrm{dl}$. The 97.5 percentile was at $4.96 \mathrm{mg} / \mathrm{dl}$ (fig. 7b).

The automated assay gave identical results with a series of human sera using either the reagent solution from Boehringer Mannheim or the self-prepared reagent (fig. 8).

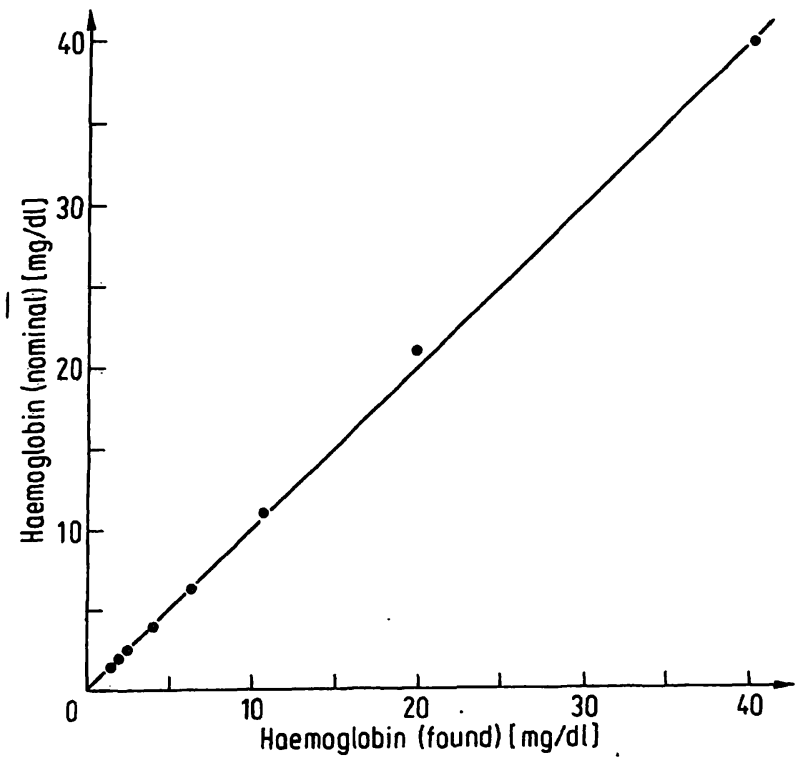

Fig. 3. Linearity of the reaction. Mixtures of the sera with the highest and lowest values shown were assayed in various relative proportions. Nominal (calculated) and found values are plotted. Data of the linear regression: $y=0.17+1.005 x ; r^{2}=0.99$ 


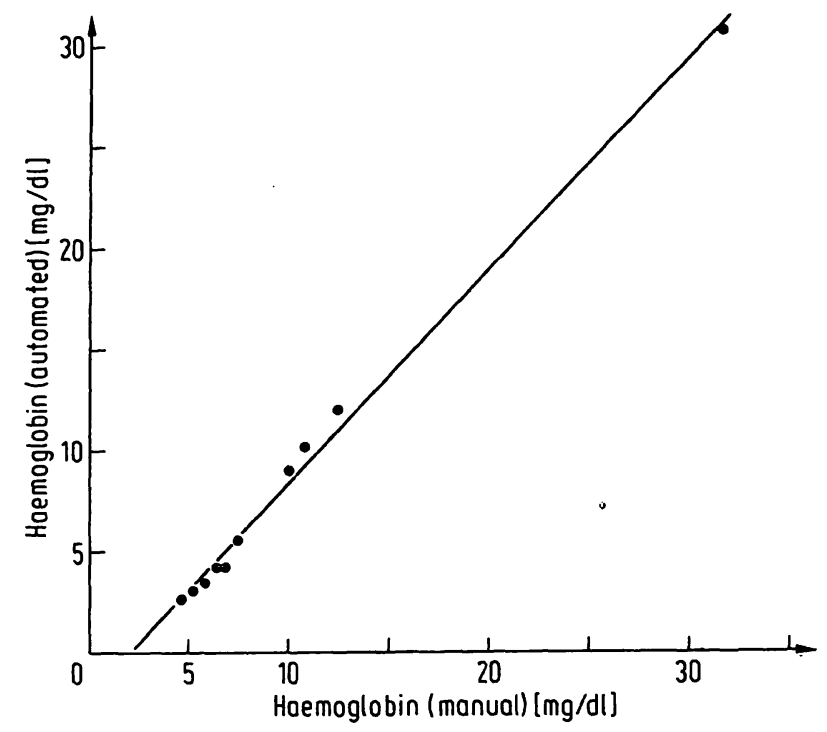

Fig. 4. Automated vs. manual method using identical 4-aminophenazone reagent mixture for determination of free haemoglobin in 10 different sera. Data of the linear regression: $y=-2.24+1.06 x ; r^{2}=0.99$.

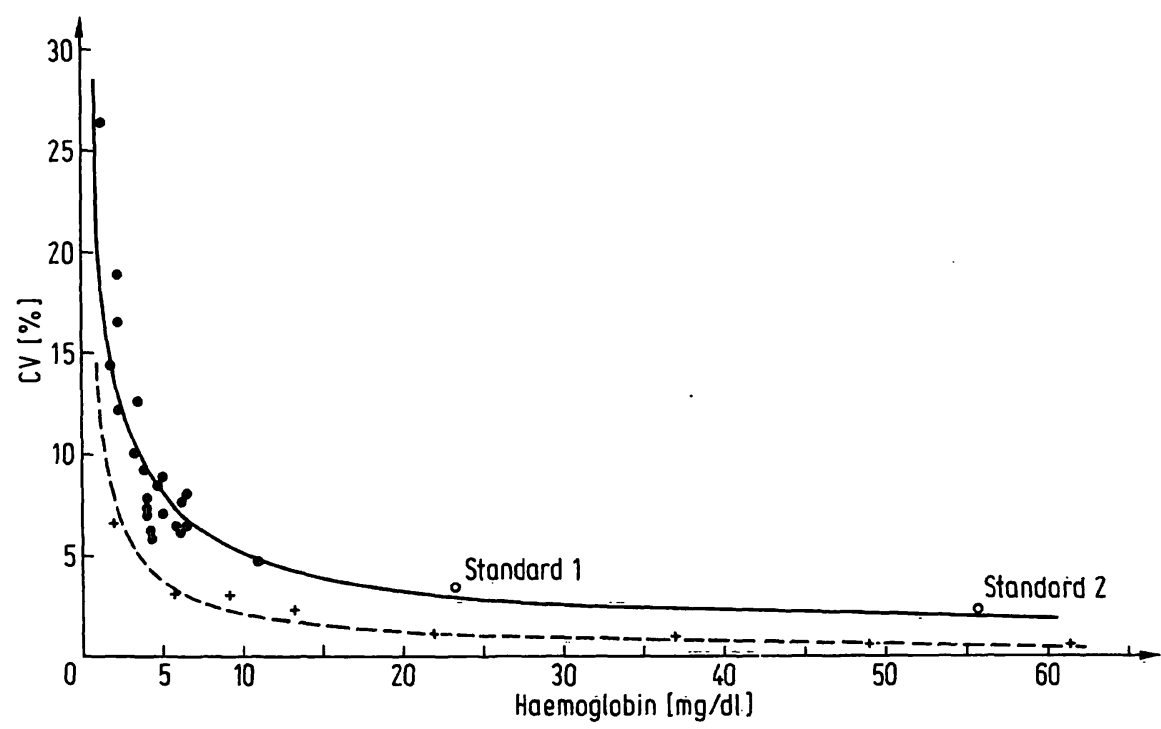

Fig. 6. Coefficient of variation $(\mathrm{CV})$ as a function of mean values $(\overline{\mathrm{x}})$ measured either in series $(+--+, \mathrm{n}=11)$ or day-to-day $(\bullet-\bullet$, $n=13$ ). In the first case (series) data of the function are: $y=14.16 x^{-0.82} ; r^{2}=0.96$. In the second case (day-to-day) data of the function are: $y=21.64 x^{-0.62} ; r^{2}=0.87$.

\section{Discussion}

Our aim was to establish a safe and practical method for the determination of free $\mathrm{Hb}$ in serum, suitable for automation on fast laboratory analysers. For this purpose a system with a fast colour reaction is needed, which uses easily accessible and non-carcinogenic chemicals. Standardisation should be possible with commercially available standards. The proposed system meets these requirements as far as possible. The 4-aminophenazone reaction system however needed some modifi-

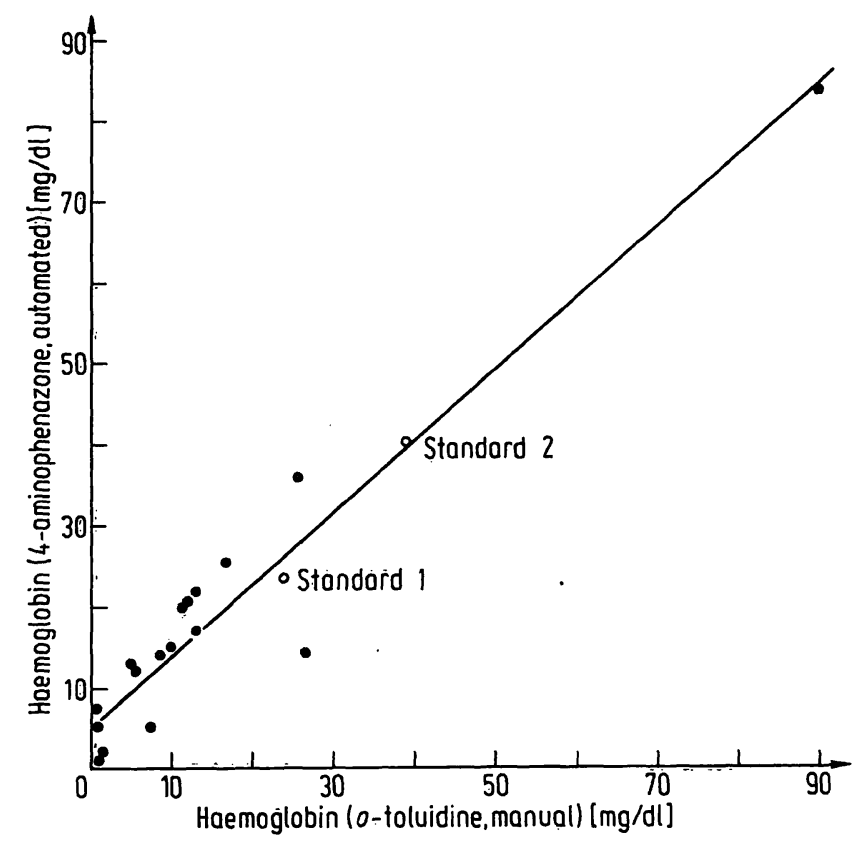

Fig. 5. Automated 4-aminophenazone assay compared to manual $o$-toluidine method in determination of free haemoglobin in 17 different human sera, and two haemiglobin cyanide standards. Linear regression: $y=5.29+0.88 x ; r^{2}=0.92$. 


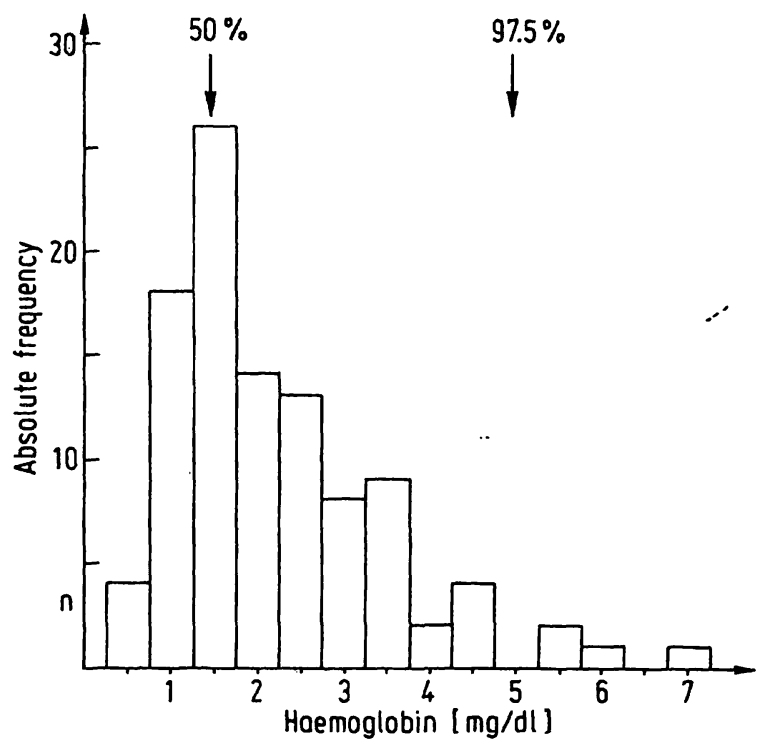

Fig. 7a. Histogram of values of free haemoglobin measured in 104 sera of normal adults with the automated method. Positions of $50 \%$ and $97.5 \%$ levels, as derived from figure $7 \mathrm{~b}$ are indicated.

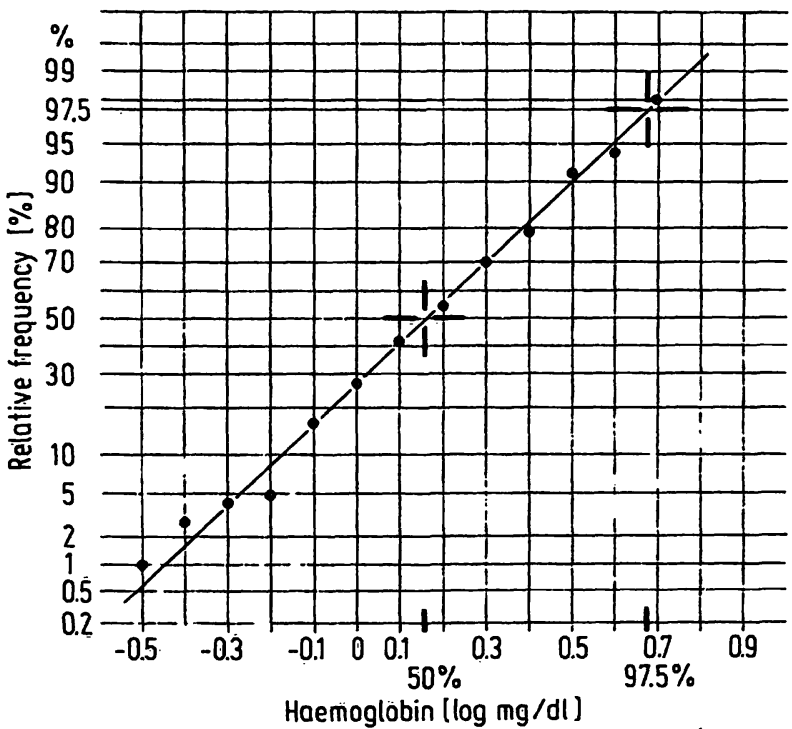

Fig. 7b. Calculation of the reference interval with normal probability paper. Logarithms of the values from figure 7a, and a cumulative percentage column were used. $50 \%$ level is at $1.46 \mathrm{mg} / \mathrm{dl}, 97.5 \%$ level at $4.96 \mathrm{mg} / \mathrm{dl}$.

desired, the values found being comparable to those obtained by the Boehringer Mannheim-reagent. The upper limit of this method is $150 \mathrm{mg} / \mathrm{dl}$ free $\mathrm{Hb}$ in serum. Higher concentrations give a non-linear response.

The reference interval in the serum of normal adults was found to be somewhat higher than that in plasma obtained by the $o$-toluidine method (5). With careful and practicable, but not extremely cautious blood drawing conditions, an upper limit of $5 \mathrm{mg} / \mathrm{dl}$ has been established in serum.

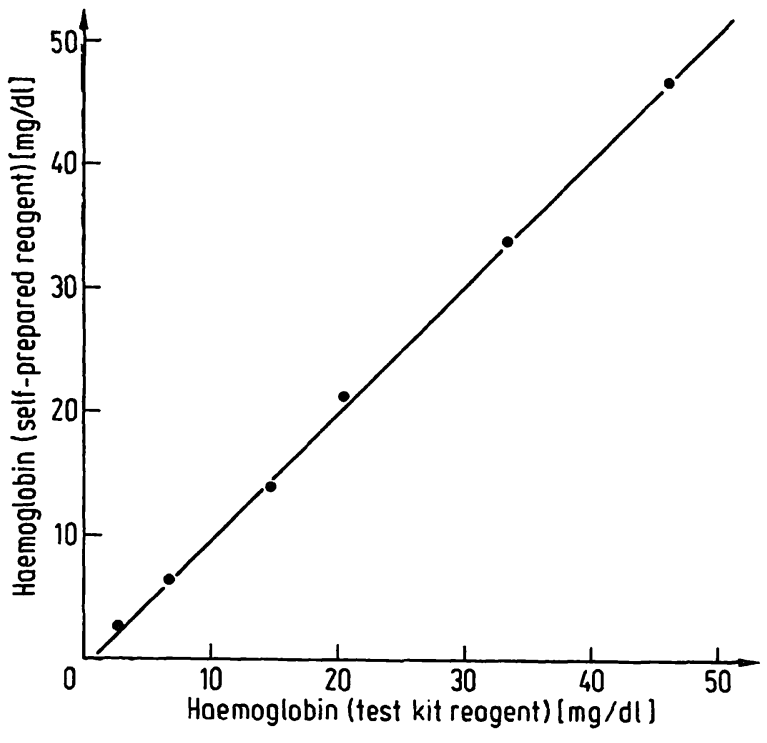

Fig. 8. Determination of free haemoglobin in a series of human sera with the automated method using either reagent from the cholesterol test kit (Boehringer Mannheim, FRG), or self-prepared reagent. Data of the linear regression: $\mathrm{y}=-0.61+1.03 \mathrm{x} ; \mathrm{r}^{2}=0.99$.

At levels of free $\mathrm{Hb}$ below $5 \mathrm{mg} / \mathrm{dl}$, plasma is not routinely suitable for this method, probably due to its unpredictable turbidity. Nevertheless, markedly elevated levels are determined correctly in heparin plasma. In cases of emergency, where time saving is more important than accuracy of values within the reference interval, heparin plasma may be used instead of serum. Similar conditions were found in animal studies with heparin plasma from calves. So far this system has only been used for the determination of free $\mathrm{Hb}$ in serum. Detection and measurement of other pseudoperoxidases (e.g. myoglobin) was not the scope of these investigations. Further studies on that subject will be performed.

The selection of haemiglobin cyanide standards to be used in the assay is critical. The Merck standards and natural haemoglobin (solutions in serum or saline) correlated well as regards $\mathrm{Hb}$-protein content and pseudoperoxidase activity. Pseudoperoxidase activity of another commercially available haemiglobin cyanide standard was found to be less than $50 \%$ of the value predicted by absorbance or protein content. We have no information on the preparation and composition of commercial standards, which may cause their marked differences in pseudoperoxidase activity.

Enzymatic activity of self-prepared haemoglobin and haemiglobin cyanide in aqueous solutions is markedly reduced at low concentrations. Self prepared standards should therefore be made in human serum, and they are stable for several weeks at $-20^{\circ} \mathrm{C}$. Repeated freezing is not recommended. The results of crossed exchange studies of 3 standards and 3 samples in two consecutive runs are shown in table 3. 
Tab. 3. Crossed application of 3 haemiglobin cyanide standard solutions (A, B, C) and 3 human sera $(1,2,3)$, as standards or samples in two subsequent runs of the automated procedure, leads to comparable results.

\begin{tabular}{lllll}
\hline & \multicolumn{2}{l}{$\begin{array}{l}\text { Standard values } \\
(\mathrm{mg} / \mathrm{dl})\end{array}$} & & $\begin{array}{l}\text { Sample values } \\
\text { (mg/dl) }\end{array}$ \\
& nominal & found & & \\
\hline A & 23.30 & 23.94 & 7.19 & 1 \\
B & 54.30 & 54.46 & 25.48 & 2 \\
C & 80.20 & 77.88 & 40.67 & 3 \\
1 & 7.19 & 7.20 & 24.74 & A \\
2 & 25.48 & 25.33 & 54.99 & B \\
3 & 40.67 & 40.84 & 80.23 & C \\
\hline
\end{tabular}

\section{References}

1. Hunter, F. T., Grove-Rasmussen, M. \& Soutter, L. (1950) Am. J. Clin. Pathol. 20, 429-433.

2. Harboe, M. (1959) Scand. J. Lab. Invest. 11, 66-70.

3. Blakney, G. B. \& Dinweedie, A. J. (1975) Clin. Biochem. 8, 96-102.

4. Henry, R. J., Cannon, D. C. \& Winkelman, J. W. (1974) Clinical Chemistry: Principles and Technics. pp. 1138-1143. New York, Harper \& Row.

5. Bauer, J. D., Ackerman, P. G. \& Toro, G. (1974) Clinical Laboratory Methods, pp. 139-140. Saint Louis, C. V. Mosby Comp.

6. Christensen, H. E. (ed.) (1976) Suspected Carcinogens, 2nd Ed., pp. 38 \& 219. Cincinnati, U.S. Department of Health, Education, and Welfare.
The Cobas Bio System is able to perform approximately 100 determinations per hour in series, while single determinations require less than 3 minutes. The specifications of this automated method should also be adaptable to other enzyme analysers, thus making available a fast, safe and reliable method for the determination of free haemoglobin in serum, or in plasma in emergency cases.
7. Slaunwhite, D., Clements, J., Tuggey, R. L. \& Reynoso, G. (1979) Am. J. Clin. Pathol. 72, 852-855.

8. Marklund, S. (1978) Scand. J. Clin. Lab. Invest. 38, 543547.

9. Trinder, P. A. (1969) Ann. Clin. Biochem. 6, 24-27.

10. Röschlau, P., Bernt, E. \& Gruber, W. (1974) J. Clin. Chem. Clin. Biochem. 12, 403-407.

11. Bradford, M. (1976) Analyt. Biochem. 72, 248-254.

12. Zyman, H., Abel, B., Bauer, K., Endler, Th. \& Gabl, F. (1980) Med. Lab. 11, 283-296.

13. Barnett, R. N. (1979) Clinical Laboratory Statistics, pp. $81-$ 85. Boston, Little, Brown \& Comp.

\author{
Dr. Kurt Bauer \\ Institut für Klinische Chemie \\ und Laboratoriumsdiagnostik \\ der Universität Wien \\ Lazarettgasse 14 \\ A-1090 Wien
}

